\title{
Estimates of ice-edge melt rates off Labrador and eastern Newfoundland, Ganada
}

\author{
S.J. Prinsenberg, I.K. Peterson and G.A. Fowler \\ Department of Fisheries and Oceans, Bedford Institute of Oceanography, P.O. Box 1006, \\ Dartmouth, Nova Scotia, Canada B2Y $4 A 2$
}

\begin{abstract}
For the winters of 1985 to 1989 , ice-edge melt rates off Labrador and eastern Newfoundland were calculated from ice charts and satellite-tracked ice beacon data. The ice charts provided ice-edge motion and ice thicknesses, while the beacons provided ice-drift rates and rates of ice-edge retreat. Over the continental slope, iceedge melt rates, ice-drift rates and heat fluxes required to melt the ice were all higher than those over the continental shelf. Ice-edge melt rates had a mean value of $18.0 \mathrm{~km} \mathrm{~d}^{-1}$ over the slope but reduced to $4.8 \mathrm{~km} \mathrm{~d}^{-1}$ over the shelf. Similarly, the mean ice-drift rate was higher over the slope $\left(41.5 \mathrm{~km} \mathrm{~d}^{-1}\right)$ than over the shelf $\left(12.7 \mathrm{~km} \mathrm{~d}^{-1}\right)$. Ice-edge melt rates increased linearly, as ice-drift rates perpendicular to the edge increased. Estimates of heat fluxes $( \pm 30 \%)$, required to melt the ice at the ice edge, reached values of $700 \mathrm{~W} \mathrm{~m}^{-2}$ for 3-day periods and had a mean of $340 \mathrm{~W} \mathrm{~m}^{-2}$ over the slope and $130 \mathrm{~W} \mathrm{~m}^{-2}$ over the shelf.
\end{abstract}

\section{INTRODUCTION}

Predicting ice-edge motion along the Canadian east coast, and variability in its southern extent, is beneficial in the planning and execution of offshore hydrocarbon exploration. A 5-year program collected ice-motion data for the area using satellite-tracked beacons and satellite imagery in order to study the response of sea ice to atmospheric and oceanographic forcing. This ice beacon data can also be used to determine ice-edge melt rates, and approximate heat fluxes to melt the ice, when ice charts for the region are available. This paper reports on the magnitude and distribution of ice-edge melt rates calculated from ice beacon tracks when beacons approached the ice edge.

\section{DATA SOURCES}

During the five winters of 1985-89, 43 ARGOS-tracked ice beacons were deployed by helicopter (Fig. 1). Although all beacons provided ice-drift rates, nine failed before they reached the ice edge and did not provide iceedge melt data. Field testing beacons at a stationary location, Peterson and Symonds (1988) estimated the positional accuracy of beacons (standard deviation) to vary from beacon to beacon, but generally to be about $0.2 \mathrm{~km}$. This implies an error in ice velocity of $0.3 \mathrm{~km} \mathrm{~d}^{-1}$ for fixes one day apart, as used in this report.

Throughout the ice season, daily ice charts for the Labrador and Newfoundland shelves are available from the Canadian Ice Centre (Atmospheric Environment Service, Ottawa). These charts are based on reports from reconnaissance flights, satellite imagery, ships and shore stations. Satellite data provide good areal distributions of the ice edge, but reconnaissance flight data provides better ice-type distributions. Ice charts, based on the most recent reconnaissance flight and satellite data, were used whenever possible. This caused the observation interval over which the beacons' ice floes melted to vary between two and ten days, having a mean of $3.8 \mathrm{~d}$.

If a position error of $5 \mathrm{~km}$ is assumed for an ice edge, then an error of $1.86 \mathrm{~km} \mathrm{~d}^{-1}$ in ice-edge velocity and iceedge melt rate should be expected for an observation time of $3.8 \mathrm{~d}$. The mean ice thicknesses around the ice beacon $\left(h_{\mathrm{b}}\right)$ or of the ice-edge region $\left(h_{\mathrm{e}}\right)$ are estimated from ice charts, which show the concentration (in tenths) of individual ice types, using the World Meteorological Organization ice classification scheme (WMO, 1970). The ice types have the following thickness ranges: ice type "1" for 0-10 cm thick ice, type "4" for 10-15 cm, type "5" for 15-30 cm, type "7" for 30-70 cm, type " 1 " for 70 $120 \mathrm{~cm}$ and type " 4 " for ice $>120 \mathrm{~cm}$ thick. For each ice type, the thickness was assumed to be the mean of its icethickness range, or $120 \mathrm{~cm}$ in the case of type "4". This value was then multiplied by the concentration of the ice type, and added to the other fractional constituents (including open water) for the area. The net result is a mean ice thickness for a $100 \%$ ice cover, or equivalently, an estimate of the ice volume per unit area that needs to be melted. For instance, beacon 23, shown on Figure 2, was on heavy offshore pack ice which consisted of $20 \%$ of type " 4 " or $120 \mathrm{~cm}$ thick ice, $50 \%$ of type " 1 " or $95 \mathrm{~cm}$ thick ice and $30 \%$ of type " 7 " or $50 \mathrm{~cm}$ thick ice, for an estimated mean ice thickness of $86.5 \mathrm{~cm}$. All of this ice melted in four days, representing a heat flux, $Q$, of $670 \mathrm{~W} \mathrm{~m}^{-2}$ for the four day period. Although the pack ice may be made up of 


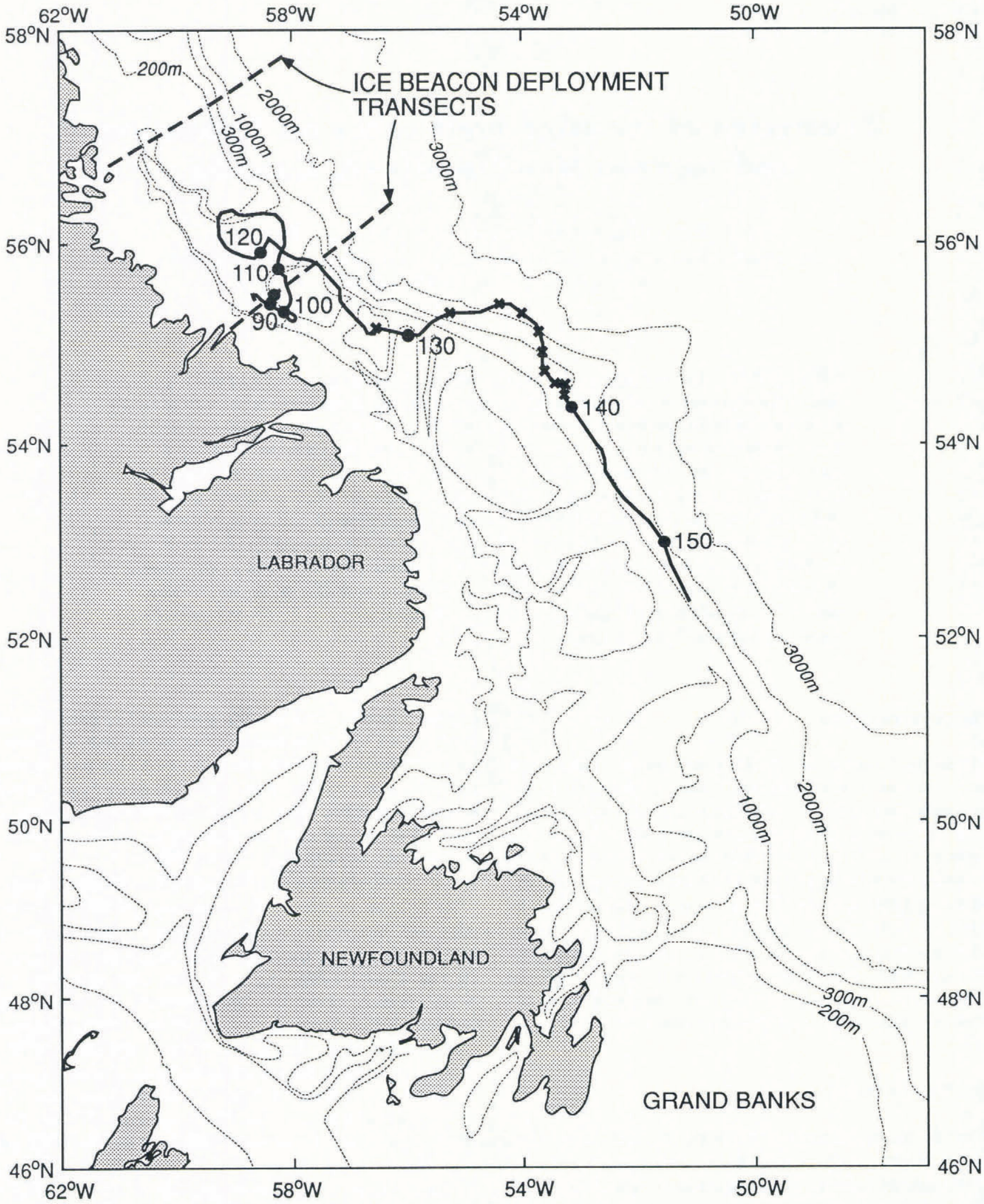

Fig. 1. The bathymetry ( $m$ ) off Labrador and Newfoundland. Ice beacon deployment transects are shown in the north and the track of the thermistor ice beacon is shown with dates of occurrence in $\mathcal{J}$ days.

several ice types, each having a possible error of $10 \%$ in concentration and $20 \%$ in thickness, the error in the mean ice thickness is dominated by the thickest ice type. If, for beacon 23, the ice concentration of the thickest ice was actually $10 \%$ higher and the thickness of each ice type was $20 \%$ higher, one obtains an ice thickness of $109 \mathrm{~cm}$ instead of $86.5 \mathrm{~cm}$, an increase of $26 \%$. Heat fluxes, $Q$, derived from these thicknesses would have similar uncertainties of $\pm 30 \%$, and should only be considered as estimates.

\section{RESULTS}

Preliminary analysis has shown that ice melt rates vary for different areas and for different ice-drift velocities. To 
(a)

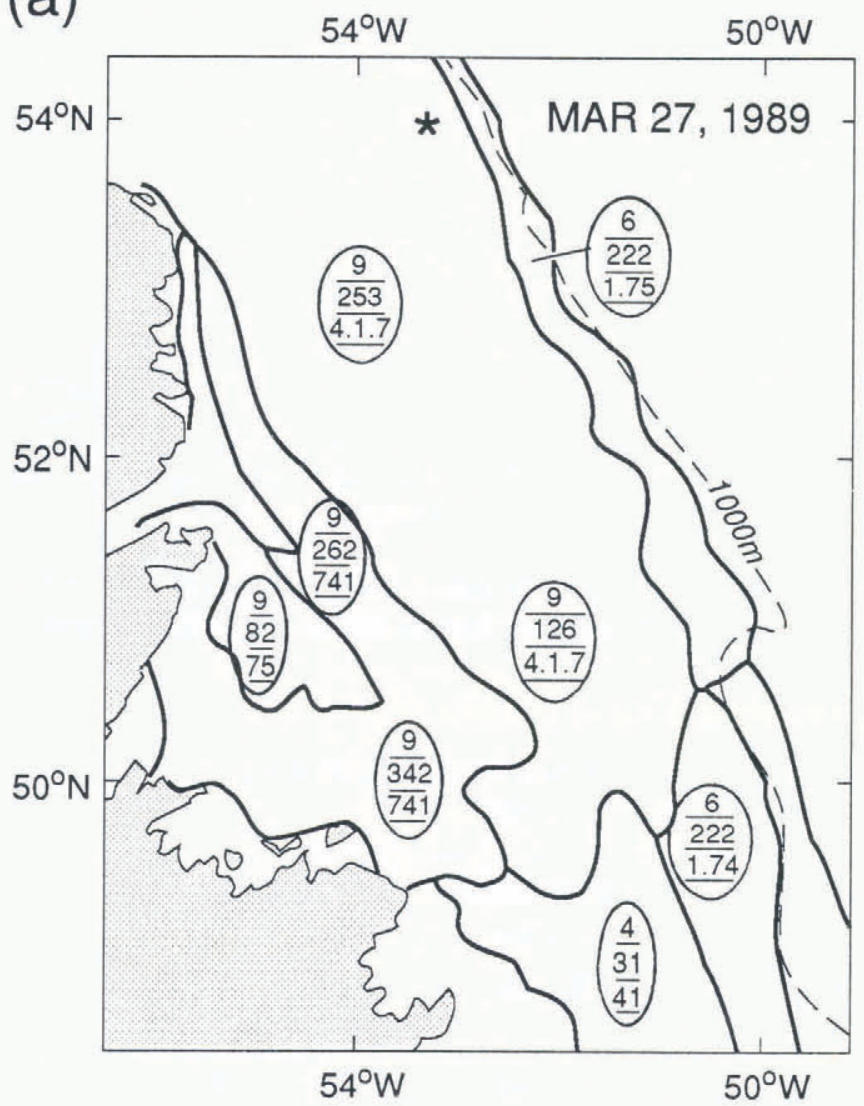

(c)

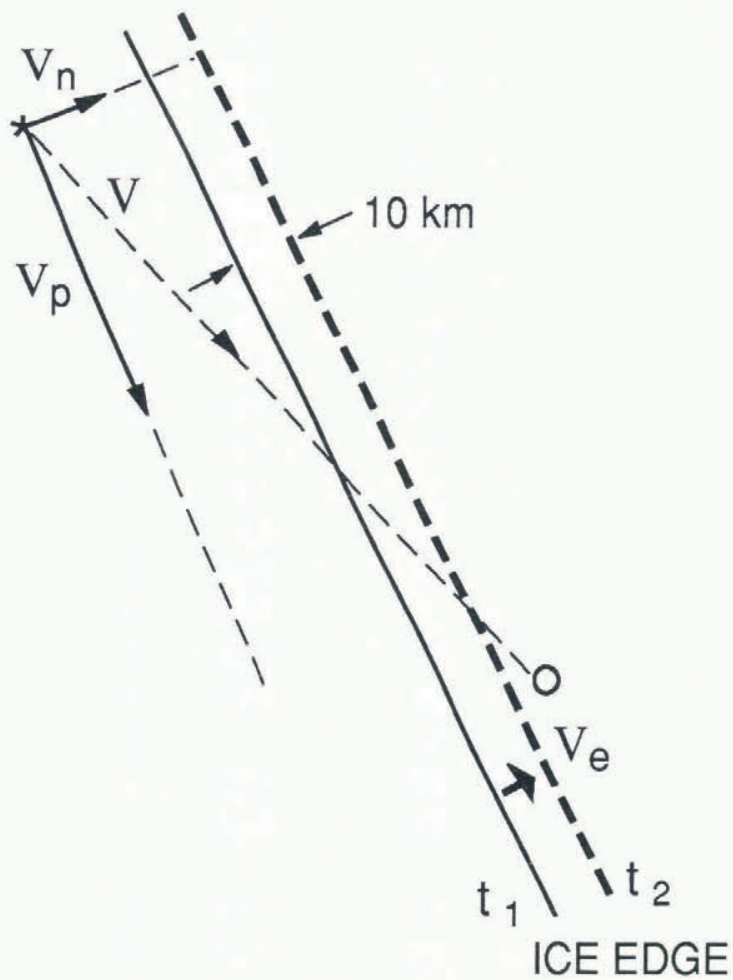

(b)

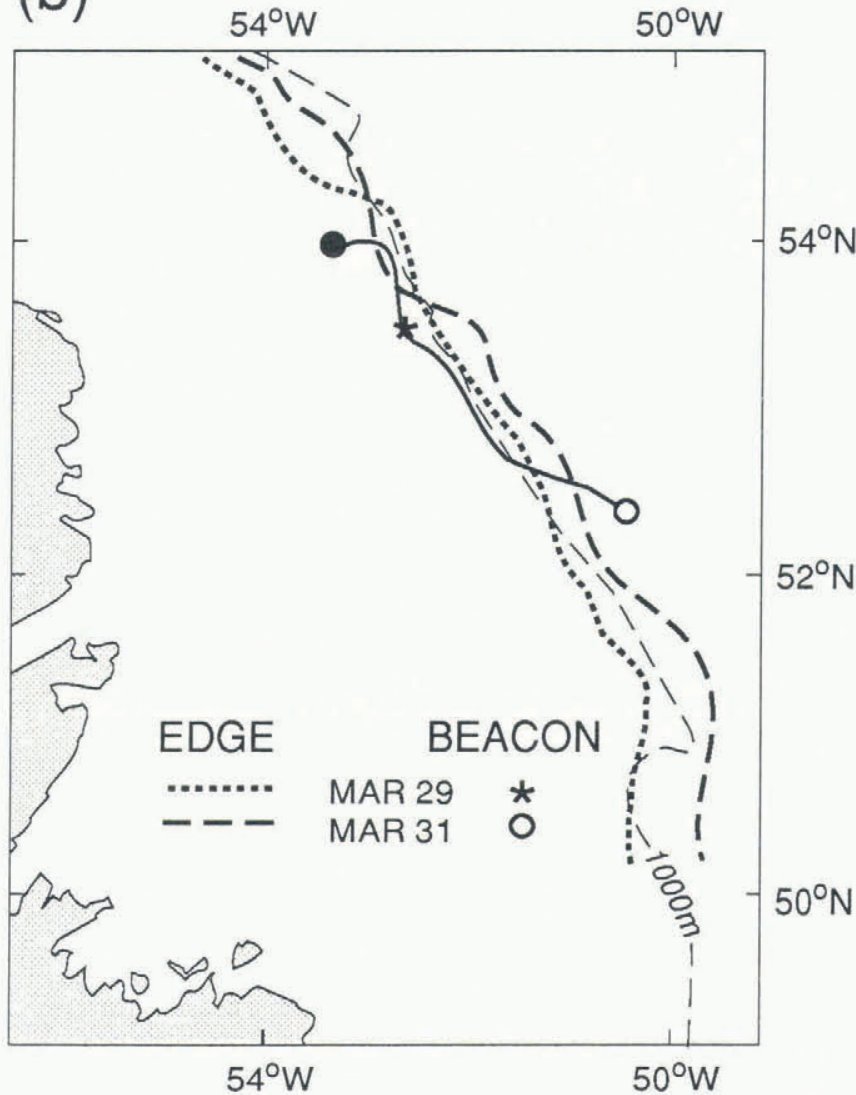

(d) BEACON \# 8646

$\mathrm{V}=\frac{190}{2.5}=76 \mathrm{~km} /$ day

$\mathrm{V}_{\mathrm{n}}=\frac{40}{2.5}=16 \mathrm{~km} /$ day

$\mathrm{V}_{\mathrm{p}}=75 \mathrm{~km} /$ day

$\mathrm{V}_{\mathrm{e}}=\frac{10}{3}=3 \mathrm{~km} / \mathrm{day}$

$\mathrm{V}_{\mathrm{m}}=\mathrm{V}_{\mathrm{n}}-\mathrm{V}_{\mathrm{e}}=13 \mathrm{~km} /$ day

$\operatorname{ICE}($ beacon $)=86.5 \mathrm{~cm}$

$\operatorname{ICE}($ edge $)=69.0 \mathrm{~cm}$

$Q=670 \mathrm{~W} / \mathrm{m}^{2}$

Fig. 2. Ice chart (a), ice-edge locations $(a, b)$ and schematic diagram (c) used to obtain ice and ice-edge drift rates for beacon no. 8646 (d) during March 1989. The ice chart for 27 March 1989 (a) shows the beacon's position and ice types (thicknesses), ice concentrations and floe-size distributions for each area using the WMO (1970) sea-ice nomenclature. (b) The ice-edge and beacon locations for subsequent days. 
understand the reasons for these variations and to parameterize the results for ice-edge prediction models, the conditions under which each ice beacon approached the ice edge will be examined. An example of the calculation procedure for beacon 23 is shown in Figure 2. This beacon approached the Labrador Sea ice edge diagonally at high speed $\left(76 \mathrm{~km} \mathrm{~d}^{-1}\right)$ between 28 and 31 March, with a velocity component normal to the ice edge $\left(V_{\mathrm{n}}\right)$ of $16 \mathrm{~km} \mathrm{~d}^{-1}$. The beacon moved along the shelf break, where the Labrador Current is located. The ice edge moved offshore $\left(V_{\mathrm{e}}\right)$ at $3 \mathrm{~km} \mathrm{~d}^{-1}$, resulting in an iceedge melt rate $V_{\mathrm{m}}=V_{\mathrm{n}}-V_{\mathrm{e}}$ of $13 \mathrm{~km} \mathrm{~d}^{-1}$. The beacon was originally on heavy pack ice, $86.5 \mathrm{~cm}$ thick, which melted in four days, requiring a heat flux of $670 \mathrm{~W} \mathrm{~m}^{-2}$ if $268 \mathrm{~J} \mathrm{~cm}^{-3}$ for the latent heat of melting is assumed.

Speeds, melt rates, ice thicknesses and heat fluxes of all 34 beacons except no. 22 are listed in Table 1. Beacon 22 is the thermistor ice beacon. Not all of its parameters

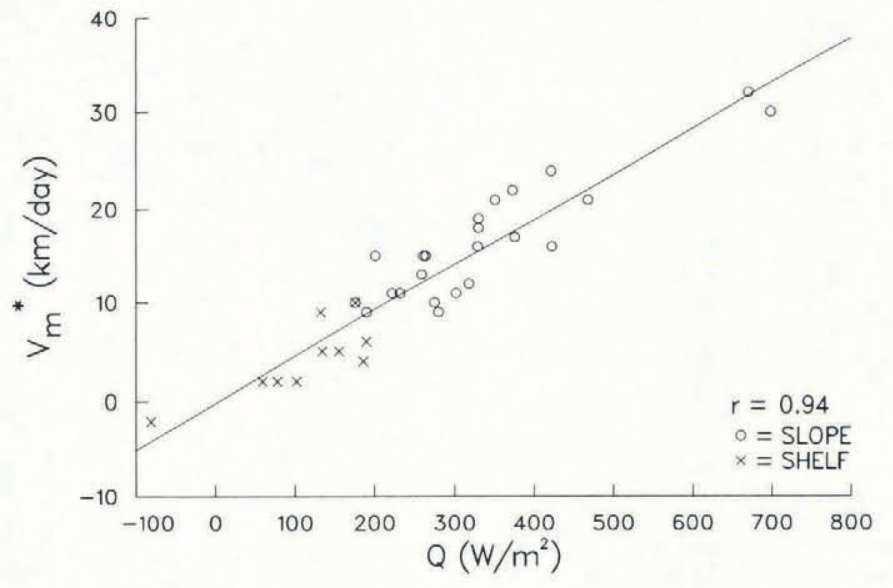

Fig. 3. Linear regression plot of the heat fluxes, $Q$, required to melt the ice around the beacons and the normalized ice-melt rate $V^{*}{ }_{\mathrm{m}}$.

Table 1. Speed, melt rates, ice thicknesses and heat fluxes of the 34 beacons reaching the ice edge. Beacon 22 is the thermistor chain. Ice thickness $h_{\mathrm{b}}$ is for around the beacon and $h_{\mathrm{e}}$ for the ice edge

\begin{tabular}{|c|c|c|c|c|c|c|c|c|c|c|c|c|}
\hline \multirow[b]{2}{*}{ No. } & \multirow{2}{*}{$\begin{array}{c}\text { Beacon } \\
\text { ARGOS } \\
\text { no. }\end{array}$} & \multicolumn{2}{|c|}{ Time } & \multicolumn{5}{|c|}{$\begin{array}{l}\text { Speed and melt rates } \\
\left(\mathrm{km} \mathrm{d}^{-1}\right)\end{array}$} & \multicolumn{2}{|c|}{$\begin{array}{l}\text { Thickness of } \\
\text { ice }(\mathrm{cm})\end{array}$} & \multirow{2}{*}{$\begin{array}{c}\text { Heat flux } \\
\left(\mathrm{W} \mathrm{m}^{-2}\right) \\
Q\end{array}$} & \multirow[t]{2}{*}{ Area } \\
\hline & & J day & Year & $V$ & $V_{\mathrm{n}}$ & $V_{\mathrm{e}}$ & $V_{\mathrm{m}}$ & $V_{\mathrm{m}}{ }^{*}$ & $h_{\mathrm{b}}$ & $h_{\mathrm{e}}$ & & \\
\hline 1 & 2347 & 51 & 1985 & 40 & 40 & 20 & 20 & 30 & 42 & 42 & 698 & B \\
\hline 2 & 2365 & 63 & 1985 & 60 & 30 & 10 & 20 & 17 & 24 & 24 & 376 & B \\
\hline 3 & 2364 & 67 & 1985 & 25 & 10 & -10 & 20 & 9 & 12 & 12 & 190 & C \\
\hline 4 & 2362 & 101 & 1985 & -19 & -5 & -19 & 14 & 16 & 32 & 32 & 329 & C \\
\hline 5 & 2341 & 109 & 1985 & 49 & 31 & 17 & 14 & 15 & 30 & 30 & 261 & C \\
\hline 6 & 2367 & 115 & 1985 & 22 & 11 & -5 & 16 & 21 & 68 & 36 & 468 & $\mathrm{C}$ \\
\hline 7 & 2348 & 115 & 1985 & -21 & -21 & -33 & 12 & 24 & 68 & 56 & 422 & $\mathrm{C}$ \\
\hline 8 & 2524 & 27 & 1986 & 75 & 55 & 23 & 32 & 15 & 13 & 13 & 201 & A \\
\hline 9 & 2398 & 27 & 1986 & 45 & 45 & 23 & 22 & 11 & 14 & 14 & 222 & A \\
\hline 10 & 2395 & 32 & 1986 & 20 & 0 & -33 & 33 & 19 & 16 & 16 & 330 & A \\
\hline 11 & 2399 & 34 & 1986 & 53 & 13 & -20 & 33 & 21 & 34 & 18 & 351 & A \\
\hline 12 & 2525 & 82 & 1986 & 47 & 13 & 3 & 10 & 10 & 46 & 29 & 176 & $\mathrm{C}$ \\
\hline 13 & 2523 & 92 & 1986 & 47 & 13 & -12 & 25 & 22 & 52 & 25 & 373 & $\mathrm{C}$ \\
\hline 14 & 2407 & 114 & 1986 & 20 & 20 & 8 & 12 & 15 & 34 & 34 & 264 & C \\
\hline 15 & 2373 & 23 & 1987 & 43 & 27 & 10 & 17 & 13 & 42 & 22 & 259 & A \\
\hline 16 & 3123 & 26 & 1987 & 46 & 33 & 12 & 20 & 18 & 37 & 25 & 330 & A \\
\hline 17 & 2378 & 26 & 1987 & 30 & 23 & 7 & 16 & 9 & 32 & 15 & 280 & B \\
\hline 18 & 2375 & 110 & 1987 & 27 & 3 & -3 & 6 & 12 & 80 & 55 & 318 & $\mathrm{C}$ \\
\hline 19 & 3325 & 34 & 1988 & 85 & 20 & 3 & 17 & 11 & 39 & 18 & 302 & A \\
\hline 20 & 3321 & 35 & 1988 & 73 & 21 & 8 & 13 & 10 & 35 & 21 & 275 & B \\
\hline 21 & 3120 & 72 & 1988 & 10 & 8 & -12 & 20 & 16 & 47 & 23 & 423 & B \\
\hline 22 & 2489 & 148 & 1988 & 18 & - & - & - & - & 71 & 47 & - & B \\
\hline 23 & 8646 & 90 & 1989 & 76 & 16 & 3 & 13 & 32 & 87 & 69 & 670 & B \\
\hline 24 & 8647 & 115 & 1989 & 22 & 8 & -2 & 10 & 11 & 45 & 32 & 232 & B \\
\hline 25 & 2368 & 117 & 1985 & -3 & -1 & -6 & 5 & 2 & 10 & 10 & 78 & D \\
\hline 26 & 2363 & 119 & 1985 & 10 & 5 & -12 & 17 & 9 & 17 & 14 & 132 & D \\
\hline 27 & 2361 & 103 & 1986 & -15 & -15 & -24 & 9 & 5 & 20 & 15 & 155 & D \\
\hline 28 & 3121 & 90 & 1987 & -5 & -4 & -8 & 4 & 6 & 45 & 44 & 190 & $\mathrm{E}$ \\
\hline 29 & 3122 & 102 & 1988 & -17 & -17 & -23 & 6 & 4 & 18 & 18 & 186 & $\mathrm{E}$ \\
\hline 30 & 3320 & 104 & 1988 & -33 & -33 & -38 & 5 & 5 & 39 & 29 & 134 & $\mathrm{E}$ \\
\hline 31 & 3318 & 104 & 1988 & -43 & -43 & -45 & 2 & 2 & 33 & 33 & 102 & $\mathrm{E}$ \\
\hline 32 & 8654 & 109 & 1989 & -3 & -3 & -1 & -2 & -2 & 47 & 35 & -81 & $\mathrm{~F}$ \\
\hline 33 & 8655 & 109 & 1989 & 5 & 5 & 3 & 2 & 2 & 70 & 25 & 59 & $\mathrm{~F}$ \\
\hline 34 & 3324 & 109 & 1989 & 5 & 5 & 3 & 2 & 2 & 70 & 25 & 59 & $\mathrm{~F}$ \\
\hline 35 & 4651 & 115 & 1989 & 1 & 0 & -3 & 3 & 5 & 45 & 45 & 115 & D \\
\hline
\end{tabular}




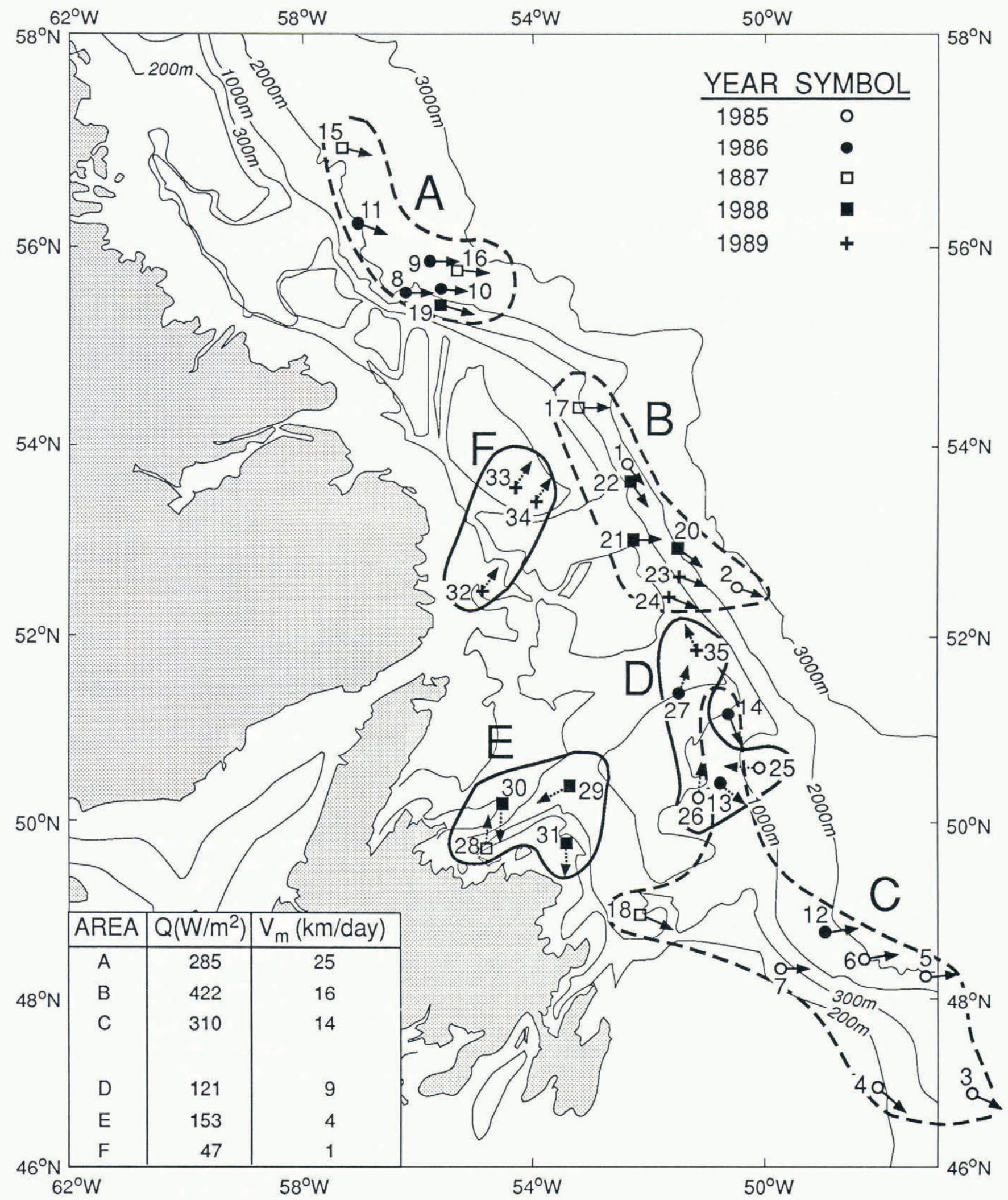

Fig. 4. Locations and directions of motion of beacons when approaching the ice edge. The beacons in areal groups $A$, $B$, and $C$ left the ice over the slope region while travelling in southeasterly directions. Those in areas $D, E$, and $F$ left the ice over the shelf region or were moving in a northerly direction. The insert lists the mean heat fluxes and ice-edge melt rates of these six areas.

are listed, since the chain's drag altered the ice-floe drift characteristics. The first part of Table 1 lists beacons which left the ice pack over the continental slope. The second part of Table 1 lists beacons whose floes melted over the shelf or were moving northwards over the outer banks, opposite to the general southeastwards ice drift. A negative ice-drift value for $V$ and $V_{n}$ indicates that the beacon left the pack ice on the inshore side of a tongue-like ice edge. A negative value for the ice-edge velocity $\left(V_{\mathrm{e}}\right)$ indicates the ice edge was retreating. In general, the 
beacons over the shelf (second part of Table 1) are characterized by lower ice-edge melt rates, lower drift rates, lower heat fluxes and later observation dates.

When ice-edge melt rates were plotted against required heat fluxes, representing vertical melt rates, a large scatter in the data resulted. This scatter is due in part to varying ice-edge thicknesses, which ranged from $10 \mathrm{~cm}$ to $69 \mathrm{~cm}$ (Table 1). When the ice-edge melt rates were normalized to a mean ice-edge thickness of $28 \mathrm{~cm}$ by $V_{\mathrm{m}}{ }^{*}$ $=V_{\mathrm{m}} \times h_{\mathrm{e}} / 28$, where $h_{\mathrm{e}}$ is the ice-edge thickness, a linear relationship was obtained (Fig. 3). This is expected, since both variables now represent one-dimensional rates of the ice-melting process. The vertical ice-melt rate of an ice column at the location of the beacon is represented by the heat flux, $Q$, while the horizontal melt rate (retreat) of a uniformly thick ice edge is represented by the ice-edge melt rate $V_{\mathrm{m}}{ }^{*}$. They are strongly coupled, as one would expect. The data are thus self-consistent and can be used with more confidence in spite of the large expected uncertainties in ice thicknesses.

Beacons whose floes melted over the shelf, or were moving northwards, were observed in three distinct areas: $\mathrm{D}, \mathrm{E}$ and $\mathrm{F}$ (Fig. 4). The beacons inshore along the Newfoundland coast (area E) were on ice trapped against the coast that melted in situ late in the season. The other beacons in areas D and F (Fig. 4) moved northwards over already cooled water as the ice edge retreated northwards. Ice-edge melt rates, and heat fluxes required to melt the ice for these three areas, had a mean of $4.8 \mathrm{~km} \mathrm{~d}^{-1}$ and $130 \mathrm{~W} \mathrm{~m}^{-2}$. Much higher values were observed for beacons leaving the ice edge over the continental slope (areas A, B and $C$ in Fig. 4). These beacons all moved in the expected southeasterly direction. The ice edge retreated at a mean rate of $18.0 \mathrm{~km} \mathrm{~d}^{-1}$ and required a mean heat flux of $340 \mathrm{~W} \mathrm{~m}^{-2}$ to melt the ice. Beacons of area $\mathrm{D}$, moving northwards, and beacons of area C, moving southwards, occupy neighbouring but overlapping areas. The large differences in their ice-edge melt rates and heat fluxes clearly indicate their dependence on the availability of oceanic heat, i.e. advancing ice edges moving over warm water versus retreating ice edges over colder water. Before discussing these differences further, the area's winter oceanographic temperature distribution must be presented.

Prior to 1987, winter water temperatures for the area were only obtained by current meters at depths of $150 \mathrm{~m}$ or deeper. For 1987-1989, salinity and temperature profiles were collected from the pack ice during the deployment of the beacons. These data showed that salt rejection during ice formation deepens the surface layer, forming an homogeneous layer whose temperature is near freezing and whose depth at times reached the shelf bottom $(200 \mathrm{~m})$. Small cross-shelf temperature gradients in the mixed layer are present which could support an onshore horizontal heat flux by advection and diffusion. The data of the $50 \mathrm{~m}$ thermistor chain revealed that a larger horizontal temperature gradient exists over the slope. Between Julian days (J days) 122 and 129, the thermistor beacon moved southeastwards over the outer banks, parallel to the coast (Fig. 1). Cold, homogeneous water conditions existed during this period (Fig. 5). As the beacon moved offshore over deeper water, between J day 129 and 132, the water temperature increased rapidly,

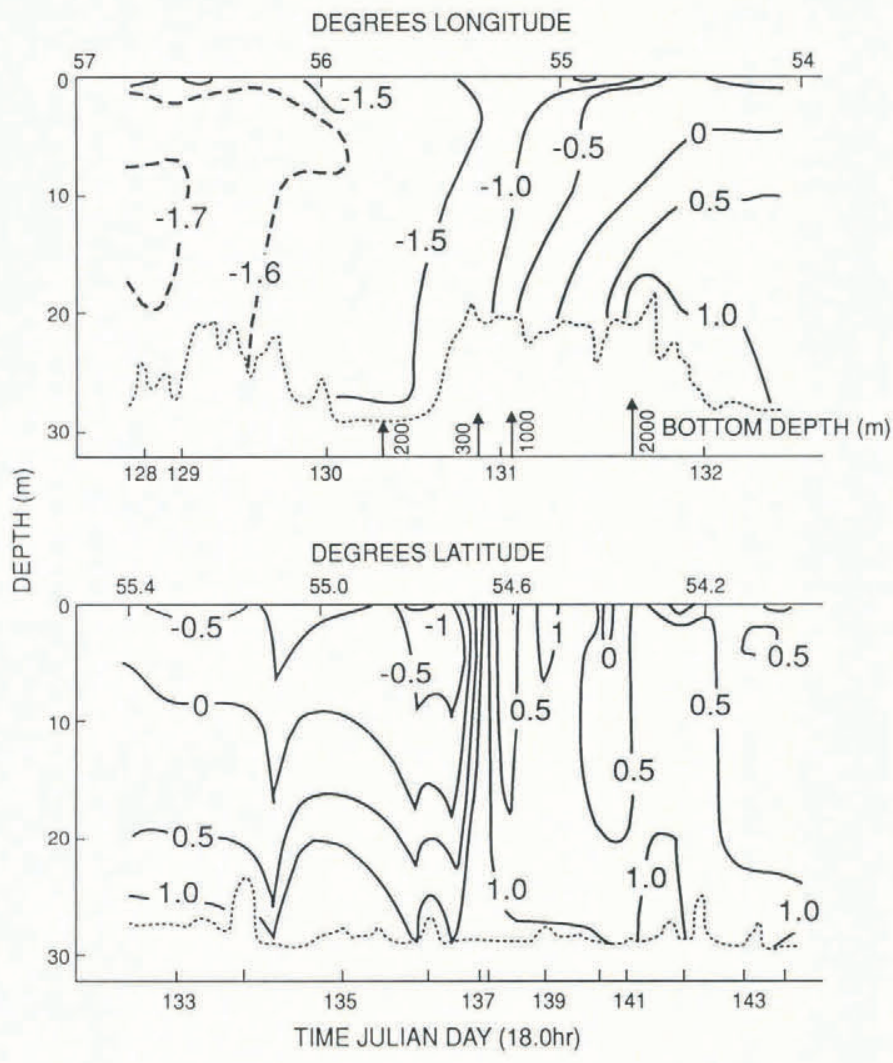

Fig. 5. Temperature cross-section along the track of the thermistor chain (shown in Fig. 1) for offshore excursion (in top panel) and for southwards excursion (in bottom panel). Dotted line shows depth location of the pressure sensor at $50 \mathrm{~m}$ wire-length, from which velocity shear between ice and ocean can be inferred.

revealing the sharp temperature gradient that existed over the slope, separating the cold shelf and warmer offshore water masses. By J day 132, the surface mixed layer had warmed up above $-1.0^{\circ} \mathrm{C}$ and had a negative vertical temperature gradient. This indicated a surface cooling process either by the atmosphere or by ice melting or both. After J day 132, the beacon moved parallel to the coast in the area where the Labrador Current is located. Stratified temperature conditions were observed up until $\mathrm{J}$ day 136 , with less stratified conditions after J day 137 when temperatures at surface and at depth increased.

\section{DISCUSSION}

Observed and normalized melt rates of ice edges reached values of $33 \mathrm{~km} \mathrm{~d}^{-1}$ with corresponding heat fluxes of $700 \mathrm{~W} \mathrm{~m}^{-2}$. These heat fluxes represent vertical melting rates of $22.5 \mathrm{~cm} \mathrm{~d}^{-1}$ or $0.9 \mathrm{~cm} \mathrm{~h}^{-1}$. Even larger melt rates $\left(1.5 \mathrm{~cm} \mathrm{~h}^{-1}\right)$ were observed by Josberger (1987), when ice moved at large velocities over warm water. Similar to those results, the results here indicated (Fig. 6) that higher heat-flux rates, $Q$, and higher ice-edge melt rates, $V_{m}$, occurred when ice-drift rates normal to the ice edge, $V_{n}$, were larger. But, since no direct ocean current data are available, it is not known if larger ice-drift rates corresponded to larger shear velocities between ice and ocean. The linear relationship between the ice-edge melt 


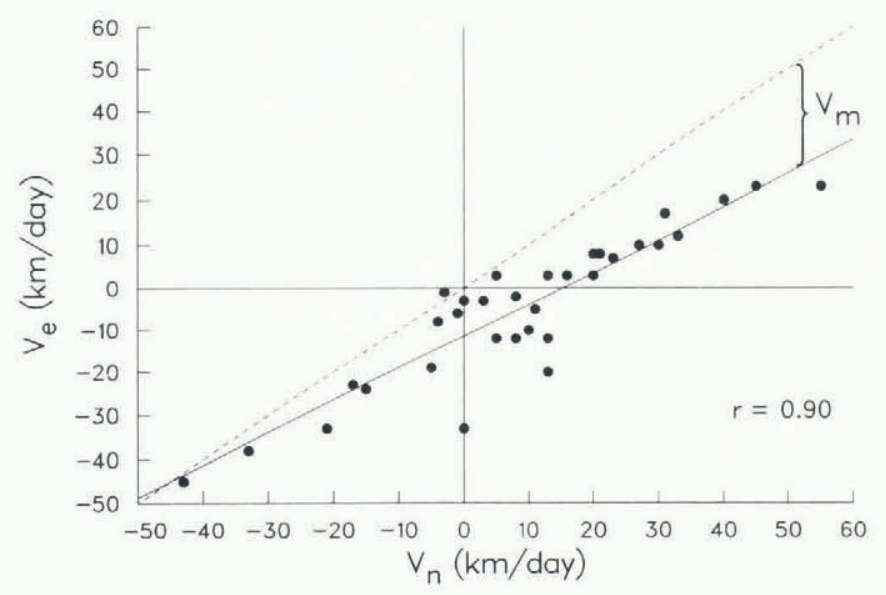

Fig. 6. Linear regression plot of the ice-edge drift rate, $V_{\mathrm{e}}$, with the drift rate normal to the ice edge, $V_{\mathrm{n}}$. The departure from a linear relationship is the ice-edge melt rate, $V_{\mathrm{m}}$, which increases linearly with the ice velocity normal to the ice edge, $V_{\mathrm{n}}$.

rate $V_{\mathrm{m}}$ and the ice drift normal to the ice edge $V_{\mathrm{n}}$, shown by Figure 6, can be parameterized by

$$
V_{\mathrm{m}}=-41+0.74\left(V_{\mathrm{n}}+40\right) \text {, }
$$

where $V_{\mathrm{m}}$ and $V_{\mathrm{n}}$ are in units of $\mathrm{km} \mathrm{d}^{-1}$. This indicates that the Labrador Sea ice edge is stationary when the ice approaches it at $15.4 \mathrm{~km} \mathrm{~d}^{-1}$, for an ice drift caused by a $10 \mathrm{~m} \mathrm{~s}^{-1}$ westerly wind. Parameterization of the melt rate as above would be suitable for ice-edge prediction models, as ice forecasters do not have information on the shear velocity but only have estimates of the ice-drift velocity $V_{n}$ obtained from the predicted geostrophic winds and from an assumed mean ice drift due to the ocean.

The heat flux required to melt the ice is a total heat flux and can come from horizontal and vertical processes in the ocean and atmosphere. Most of the heat flux comes from the ocean since, even in the presence of an ice cover, the ocean loses heat to the atmosphere during winter and early spring months. Using climatic mean atmospheric inputs for the Labrador coast region, Maykut and Untersteiner's (1971) model predicted oceanic heat flux values for thin ice ranging from $114 \mathrm{~W} \mathrm{~m}^{-2}$ in January to $-18 \mathrm{~W} \mathrm{~m}^{-2}$ in May. With a thin, $10 \mathrm{~cm}$ layer of snow on the pack ice, the fluxes ranged from $33 \mathrm{Wm}^{-2}$ to $-4 \mathrm{Wm}^{-2}$. Although these fluxes can be ignored considering the large uncertainties $( \pm 30 \%)$ in the heat fluxes, results do show that the ocean not only provides heat to melt the ice but, except for May, also provides heat to the atmosphere. Therefore, the calculated heat fluxes of Table 1 should be considered as minimum estimates of fluxes provided by the ocean.

Numerical ice models (Ikeda and others, 1988) have simulated ice-cover advance and retreat along the Labrador coast using a mean monthly upward heat flux of $35 \mathrm{~W} \mathrm{~m}^{-2}$ to the ice cover over the $100 \mathrm{~km}$-wide shelf. This $35 \mathrm{~W} \mathrm{~m}^{-2}$ flux was applied uniformly to the combined $100 \mathrm{~km}$-wide shelf and slope area. But, as shown above, the horizontal temperature gradient indicates that nearly all of the heat is used over the narrow $20 \mathrm{~km}$ slope area. If
$10 \mathrm{~W} \mathrm{~m}^{-2}$ is taken as a mean value for the shelf area, then this would require a monthly mean heat flux of $135 \mathrm{~W} \mathrm{~m}^{-2}$ for the slope area to bring the mean monthly heat flux to $35 \mathrm{~W} \mathrm{~m}^{-2}$. However, offshore storm events that produced the large observed heat fluxes, only occur one third of the time. If, during the rest of the month, a heat flux of $10 \mathrm{Wm}^{-2}$ is present over the slope, then $385 \mathrm{~W} \mathrm{~m}^{-2}$ is needed during the offshore wind events in order to bring the monthly mean value to $135 \mathrm{~W} \mathrm{~m}^{-2}$ for the slope area and to $35 \mathrm{~W} \mathrm{~m}^{-2}$ for the total shelf and slope area. Thus, the large heat fluxes observed over the narrow slope for the short period events are needed to provide, on a monthly time scale, the $35 \mathrm{~W} \mathrm{~m}^{-2}$ flux of heat to the pack ice used by models to simulate the seasonal advance and retreat of the pack ice.

\section{CONCLUSION}

Ice-drift rates for the ice-edge region of the Labrador Sea reached values of $85 \mathrm{kmd}^{-1}$ and had a mean rate of $40.5 \mathrm{~km} \mathrm{~d}^{-1}$. Ice is advected by the southwards-flowing Labrador Current and pushed along by the predominantly northwesterly wind. The wind causes upwelling and shoreward advection of warm water along the slope area, providing a large continuous heat flux that melts any ice that leaves the shelf area. Ice edges retreated at rates up to $32 \mathrm{~km} \mathrm{~d}^{-1}$ and heat fluxes required to melt the ice of the ice edge reached $700 \mathrm{~W} \mathrm{~m}^{-2}$. Their mean values over the slope were $18.0 \mathrm{~km} \mathrm{~d}^{-1}$ and $340 \mathrm{~W} \mathrm{~m}^{-2}$. Over the shelf, and for ice moving northwards, melt rates are much lower as ice is moving over previously cooled water.

The observed ice-edge melt rates and heat fluxes are based on short events observed over a narrow ice-edge area when beacons generally moved offshore. Monthly mean heat fluxes, for the total pack ice used in numerical models, would only include a few of these events and distribute the heat over a larger area. Their monthly mean values are thus an order smaller than those presented in this paper. The large melt rates of some of these events indicate that thermodynamic processes cannot be ignored in models predicting ice-edge motions in the region. Although regression analysis indicated larger ice-edge melt rates for increasing ice-drift rates, which can be parameterized for ice-edge models, a more detailed data set on shear velocities between the ice and the ocean is required to carry out this analysis properly.

\section{ACKNOWLEDGEMENTS}

The authors thank Drs E.B. Bennett and M. Ikeda for reading and suggesting changes to the original manuscript. The sea-ice program is funded through the Federal Panel of Energy, Research and Development.

\section{REFERENCES}

Ikeda, M., G. Symonds, and T. Yao. 1988. Simulated fluctuations in annual Labrador sea-ice cover. Atmosphere-Ocean, 26(1), 16-39. 
Josberger, E.G. 1987. Bottom ablation and heat transfer coefficients from the 1983 marginal ice zone experiments. F. Geophys. Res., 92(C7), 7012-7016.

Maykut, G.A. and N. Untersteiner. 1971. Some results from a time-dependent thermodynamic model of sea ice. 7. Geophys. Res., 76(6), 1550-1575.

Peterson, I.K. and G. Symonds. 1988. Ice floe trajectories off Labrador and eastern Newfoundland: 1985-1987.
Can. Tech. Rep. Hydrogr. Ocean Sci. 104.

World Meteorological Organization. 1970. Sea ice nomenclature. Geneva, World Meteorological Organization. (WMO Report 259.)

The accuracy of references in the text and in this list is the responsibility of the authors, to whom queries should be addressed. 